$$
\begin{aligned}
& \begin{array}{c}
B \\
491
\end{array} \\
& \text { Bs Ts } \\
& \text { के } 45 \text { 2 1 ? }
\end{aligned}
$$

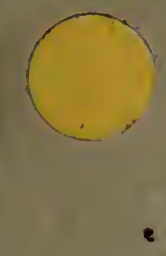

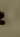

0
in
$\frac{m}{n}$
$i$ 
ON ARISTOTLE

AS A BIOLOGIST

WITH A

PROOEMION ON HERBERT SPENCER

BiEING THE HERBERT SPENCER LECTURE DELIVERED BEFORE TIIE UNIVERSITY OF

OXFORD, ON FEBRUARY I+, I9I3

B)

D'ARCY WENTWORTH THOMPSON

Price One shulling net

OXFORD

AT THE CLARENDON PRESS I 9 I 3 


\section{ON ARISTOTLE}

AS A BIOLOGIST

WITH A

PROOEMION ON HERBERT SPENCER

BEING THE HERBERT SPENCER LECTURE DELIVERED BEFORE THE UNIVERSITY OF OXFORD, ON FEBRUARY I4, I9I3

BY

D'ARCY WENTWORTH THOMPSON

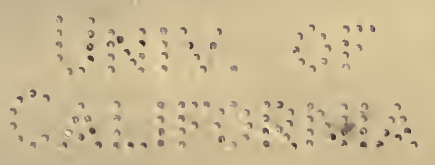

OXFORD

AT THE CLARENDON PRESS

I9I3 


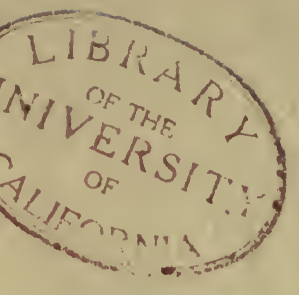

HENRY FROWDE

PUBLISHER TO THE UNIVERSITY OF OXFORD LONDON, EDINBURGH, NEW YORK, TORONTO MELBOURNE AND BOMBAY

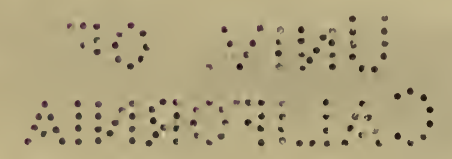




\section{ON ARISTOTLE AS A BIOLOGIST:}

\section{WITH A PROOEMION ON HERBERT SPENCER}

HeRbert Spencer was born when last century was young, and this century was in its cradle when he passed away. Ipse Epicurus obit, cried the poet of a philosophy which of all the systems of antiquity was most kindred to Spencer's own. A like thought passed through many men's hearts when Herbert Spencer died-men of all nations and languages, for while Spencer lived his voice reached far and wide, even to the ends of the earth. He was a philosopher not speaking to the philosophers, nor teaching in the schools; but he had a gift and a message, so in touch with the temper of his time, that it made him a speaker, ex cathedra, to the world. No philosopher of modern times, not Kant himself, has exercised in his lifetime so wide a dominion. Only here and there, among men of a very different stamp, in men like Byron or Rousseau or Tolstoi, do we see that strange power of captivating the imagination of an age, of speaking with a voice that goes out into all lands. The foundation under whose auspices we gather here, the gift of an Indian scholar, reminds us of Spencer's influence in the East : in still more distant Japan his counsel was sought when the nation issued from its seclusion to join in the labours and anxieties of the modern world; he stirred the restless blood of Russians and of Poles; in America his books were read far more sedulously than at home; and all this great influence was won without literary art 
or any charm of magic words, without the fire of Tolstoi, the poetry of Heine or of Byron, the beauty of Rousseau's prose. But Spencer had something in common with all those men, as his popularity was commensurate with their own. And that bond of likeness lay in the fact that to men weary of old trammels and of old burdens he seemed to point, he tried to offer, ${ }^{\mathbf{1}}$ a way of emancipation, a path of deliverance from creeds outworn. By the world which he addressed he was welcomed and acclaimed, in the spirit in which Heine wished to be remembered, as a gallant soldier, ein tapfrer Krieger, in the fight for freedom.

Let us recall, with all brevity, some few circumstances of Spencer's life, that our minds may keep his memory green.

Of that narrow, ascetic, and fiercely independent home of his boyhood we have all read or heard-with its atmosphere of struggle, of criticism, of scientific and political discussion, unrelieved by humour, by letters, or by art. We remember how he went forth as a lad to labour, at an age when men have not yet come up to the University ; and how, as an engineer's assistant, he helped to plan bridges and direct gangs of navvies on the great new road to Birmingham and Crewe, and shared in all the fever and haste of that great period of construction. These were the years that he spoke of afterwards as " the futile part of his life'; but it is as plain as an open book that they were years in which his mind was moulded and his mechanical outlook on phenomena developed and confirmed. Again, we remember his years of journalism, during which, after the appearance of his first book, he soon emerged from a lonely life, and with the friendship

' Compare the opening passage of Social Studies (1864). " "Give us a guide," cry men to the philosopher. "We would escape from these miseries in which we are entangled," ' \&c. 
of George Eliot and Lewes, Huxley, Tyndall, and many more, found his place in the world of London. Henceforth, his life was so quiet, simple and retired, that we might say of him, as Heine said of Kant, ' Er hatte weder Leben noch Geschichte.'

In 1855, in the Principles of Psychology, Spencer affirmed his belief in the 'development hypothesis ', $\mathbf{1}$ as accounting for the origin of species; and as accounting also for the successive association of ideas, and so, by their becoming 'innate' and transmissible from generation to generation, for the gradual development of mind: which latter investigation, I need hardly say, has since been continued, by a long line of evolutionary psychologists, in their several and divergent ways. It is curious to learn from his Autobiography that about this time, in his talks with Huxley, it was the latter who still preserved a guarded attitude, and Spencer who urged upon him, but with still inadequate and unconvincing arguments, the hypothesis of organic evolution.

Five years later, a year after the publication of the Origin of Species, Spencer brought out the prospectus of his Synthetic Philosophy, that heroic effort to combine, in a Philosophy of Evolution, the whole range of physical, mental, and social science. To discover and trace that one identical phenomenon of Evolution, in the progress of civilization, in the development of mind, in the course of nature, in the history of the Universe, was his single and life-long aim.

He found such tools as he worked with in the current tendencies of political and economic thought, and in the recent discoveries or generalizations of science. Of these latter, on the physical side, the greatest was the principle

1 As already, in 1852 , he had done in his essay on the Development Hypothesis. 
of the Conservation of Energy, the final result of the doctrine of the correlation of the physical forces, in establishing which Rumford had led the way; while on the biological side he drew inspiration from the fact, rindicated by Aristotle, developed by Wolff and MilneEdwards, made into an aphorism by Von Baer, that as the organism grows it grows continually from the simple to the complex, from the homogeneous to a greater and greater heterogeneity. ${ }^{1}$

But many years before Von Baer a greater than he had enunciated the same truth, and had set it forth in even plainer and better words. It was Goethe, in his $Z u r$

Morphologie, ${ }^{2}$ who laid it down as a law that "the more imperfect a being is, the more do its individual parts resemble each other, and the more do these parts rescmble the whole. The more perfect the being is, the more dissimilar are its parts. In the former case the parts are more or less a repetition of the whole; in the latter case they are totally unlike the whole. The more the parts resemble each other, the less subordination is there of one to the other; and subordination of parts is the mark of high grade of organization.' 3 Now these words are found in the Life of Goethe, by Lewes, Herbert Spencer's closest friend. We can scarce avoid the inference that it may have been the poet's insight and the poet's words, quite as much as Von Baer's, that crystallized in his famous formula of evolution. And the inference is confirmed by the fact that, though it was to Von Baer that Spencer was afterwards in the habit of ascribing the law, yet, on the first

1 The 'law of differentiation', or of 'organic progress', was first propounded by Spencer in his essay on Progress, its Law and Cause (I857), where he argued that it was also the law of all progress whatsoever.

2 I 807 (written in I795). Republished in Goethe's Werke, xxxvi, p. 7 .

${ }^{3}$ Lewes, Life of Goethe (1855), 3rd ed. I875, p. 358. 
occasion when he mentions it, he speaks of it as having been established 'by the investigations of Wolff, Goethe, and Von Baer'. 1

As in former days Descartes, and as Democritus and Epicurus in days of old, so did Spencer find in matter and in motion, or rather in matter and in force, the fabric of a world. He draws a broad picture, confessedly of a mechanical kind, of alternate cosmic rhythms of the Universe, in which as motion is dissipated, so matter cleaves from the dispersed and homogeneous into more coherent and more segregated shapes; until in the turn of the great wheel, a new redistribution of matter and motion takes place, and evolution is inevitably followed by dissolution at its heels; so the whole present order perishes, exitio terras cum dabit una dies. Nevertheless, so vast is the cosmic rhythm, that again the wheel turns, and the dust and ashes of a Universe are co-ordinated and integrated anew, to make 'another and another frame of things, For ever!'

All the while Spencer recognizes that Space, Time, Motion, and Matter itself are remote from Absolute Reality, and have their source in our own Empiricism. The 'Persistence of Force' is the only truth which transcends experience ; and what we ultimately mean by, the persistence of force is a cause which transcends our conception and our knowledge.

In his Biology Spencer takes for his keynote his conception of life, as having for its chief characteristic a continuous adjustment of the organism to its environment, of its internal to its external relations. So structure $v C$ follows upon function and functional need, and hereditary transmission hands on to the next generation the advances

1 Von Baer himself claimed no priority. 'Dieses Gesetz ist wohl nie verkannt worden,' Zur Entwicklungsgesch. (I), p. I53. 
$3\{$ that the past generation has made: life produces organization, and not organization life. Again, in certain

L chapters which are by no means the least interesting of the book, he shows, ${ }^{1}$ after the fashion of the engineer, and from the experience of the bridge-builder, ${ }^{2}$ how the principles of stress and strain are concerned in the fabric, and in the physiology, of the organism; how physical and mechanical relations alter in the organism with sincreasing bulk; ${ }^{3}$ and how incident forces of gravity, growth, and pressure control or determine the shape of leaf and bone and single cell. Under the guidance of a wholesome restraint, a whole school of morphologists, $\checkmark$ Roux's school of Entwickelungsmechanik, are now investigating these self-same problems, and so bringing to the help of morphology some of those physical concepts which began to be the stock-in-trade of the physiologists when Majendie wrote his Leçons sur les phénomènes physiques de la Vie (1830).

In the Ethics, Spencer undertakes to establish ' rules of right conduct ' on a scientific basis, and he does not minimize the difficulty of getting rid of 'supernatural ethics', nor of forming a science of ' what ought to be '. Nevertheless, he does his best to connect absolute Ethics with his universal formula of cosmic evolution and equilibration. Ethics must be based on science, and not on metaphysics. There is, he holds, not only an Ethic for all reasonable beings, but a principle of Ethic for all living things; life

1 As in an earlier essay on The Law of Organic Symmetry, 1859.

2 Even in his Sociology, where he discusses the place of the pontifices in an archaic priesthood, he seems to dally with peculiar affection over these old bridge-builders.

- A curious corollary, or case in point, is found in the fact that definite limits are set to the size of a terrestrial animal, and still more to that of a flying bird, while the aquatic animal, comparatively immune from gravity, increases in locomotive speed, as a ship does, the bigger it becomes (Princ. of Biology (2nd ed.), i. I 56). 
and not reason is the essential thing. All conservation implies evolution, and individuality is developed by the inevitable changes of a changing world. ${ }^{1}$ So Spencer labours, but perhaps in vain, to make the best of the bellum omnium contra omnes, to find in the biological process of adjustment a continual tendency to happiness, and in sociological evolution a tendency to ultimate harmony ; in the which a somewhat complacent altruism shall satisfy the egoist, and pleasure will consist in actions which are salutary to the individual and the race. All very much as $\mathrm{Mr}$. Bridges puts it :

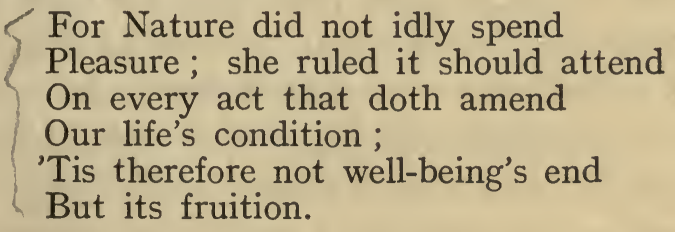

So through all the circle of the sciences, Spencer tried to satisfy that craving inherent in mankind for a constructive system, which shall, in a single unity, frame all the phenomena of the world : for such a unification as in Aristotle's hands had endured unshaken for nigh two thousand years. To bring the world of fact and the world of Intelligence into the unity of a system is the task which all philosophers essay, in the light of the knowledge and the spirit of their time; but as knowledge grows, and men's ways and circumstances change, so does Philosophy itself, like all else in the world, undergo its own inevitable and endless evolution-giving place, if not to the better, to the new. ${ }^{2}$

1 'C'est là l'idée capitale qu'il ajoute aux doctrines de Zénon, de Spinoza et de Volney:' Guyau, La Morale anglaise contemporaine, I 885 , p. 268.

2 The last words are quoted from Alden, A Study of Death (1895), I903, p. I76; cf. North Amer. Review, January I9I 3. 
But let me not omit to say a word of Spencer's attitude to 'the insoluble mystery', of his confessio ignorantis, of his share in that Agnosticism for which Huxley found a name. 'At the utmost extent of his tether,' to borrow words from Locke, ' he sat down in quiet ignorance of those things which he found to be beyond the reach of his comprehension.'

By a bold abstraction Spencer puts asunder things that our thought insists shall be conjoined. And, through relation, association, and causation, he carried to their bitter end those theories of empiricism, and of the relativity of knowledge, that were no new thing in philosophy, but had percolated down to him through Mansel and through Hamilton, from Locke and Hume and Kant, through all those who had discussed the possibility of knowledge in itself; carried them to their bitter end, and stripped them bare of the garments of the old philosophy, of intuition, or of faith, wherewithal they were wont to be clothed. And in so doing it may seem to many of us that he stopped short but a little way along that steep and narrow road, that parvus trames, which is the Pathway from Appearance to Reality.

Ipse Epicurus obit, decurso lumine vitae-' when the lamp of life ran low'. And so too Spencer died-as it were but yesterday-full of years and of honour. And to the multitude of friends, disciples, mourners, gathered at his grave, a wise and eloquent man spoke a few noble words. He spoke of Spencer's deep affections and lasting friendships, of the houses that he entered as an habitual guest and honoured friend; of the magnitude of his task, of his unwearied struggle, and of his joy when his work was done; of his 'coherent, luminous, conception of the evolution of the world' ; of his exaltation of man's individual freedom, of the ethical 
purpose that underlay his quest of truth. And, lastly, Lord Courtney spoke of Spencer's last brave effort, in the Riddle of the Universe, to face and scrutinize the implacable facts of life : of how in the end he had confessed himself overawed by the vastness of the unknowable, appalled by the great vision of Everlasting Law, and silent in the contemplation of the Infinite and the Eternal.

And now that I have tried to pay, in not ungrateful words, our annual tribute to Spencer's memory, as to one who has been a great influence in our world, whose words have become part of our familiar speech, and whose thought has interpenetrated and commingled with our own, let me proceed for what time remains towards another, but I hope a cognate, theme.

In passing from Spencer to Aristotle, we turn from the one philosopher of our own times who has made biology an intrinsic part of his sociology and his psychology, to the great biologist of antiquity, who is maestro di color che sanno, in this science as in so many other departments of knowledge. And by the analogy of contrast, we can scarce think of Herbert Spencer's biology without recurring to that of Aristotle, so reverting from a great teacher of mechanical causation to him who taught us our first clear lessons of the phenomena of Life. But, save only by repeating what I have said, that Spencer came to the study of biology in the spirit and with the equipment of the engineer, and by declaring that Aristotle seems to me to have been first and foremost a biologist, by inclination and by training, I will not attempt to pursue the comparison. Let us simply glance at some parts of Aristotle's Natural History, and attempt to show, in a partial and elementary way, the influence of that study upon his mind. 
The naturalist is born a naturalist, and we may be sure that Aristotle was a lover and a student of nature from a boy; but it would help us to trace the relation of his biological studies to his philosophical work if we could ascertain when his chief biological work was done. It has often been held that Aristotle devoted himself to biology as an old man's recreation, after his retirement to Euboea. This theory is not adequate, and I do not think it is true. Another legend, that Alexander sent his pupil? specimens from his campaigns, Cuvier accepted and Humboldt denied; there is no evidence for it, direct or indirect, in Aristotle's writings, and this tradition also I believe to be worthless. But there is evidence, of a geographical kind, that helps us to answer our preliminary question.

Among the isles of Greece there is a certain island, insula nobilis et amoena, which Aristotle knew well. It lies on the Asian side, between the Troad and the Mysian coast, and far into its bosom, by the little town of Pyrrha, runs a broad and sheltered lagoon. It is the island of Lesbos. Here Aristotle came and spent two years of his life, in middle age, bringing his princess-bride from the petty court of a little neighbouring state where he had already spent three years. It was just before he went to Macedon to educate Alexander ; it was ten years later that he went back to Athens to begin teaching in the Lyceum. Now in the Natural History references to places in Greece proper are very few indeed; there is much more frequent mention of places on the northern and eastern coasts of the Aegean, from Aristotle's own homeland down to the Carian coast; and to places in and round that island of Lesbos, or Mitylene, a whole cluster of Aristotle's statements and descriptions refer. Here, for instance, Aristotle mentions a peculiarity of the deer on 
a neighbouring islet, of the weasels by the wayside near another island town. He speaks of the big purple Murex shells at Cape Lectum, and of the different sorts of sponges found on the landward and the seaward side of Cape Malia. But it is to the lagoon at Pyrrha that Aristotle oftenest alludes. Here were starfish in such abundance as to be a pest to the fishermen; here the scallops had been exterminated by a period of drought, and by the continual working of the fishermen's dredge ; here the sea-urchins come into season in the winter time, an unusual circumstance. Here among the cuttlefishes was found no octopus, either of the common or of the musky kind; here was no parrot-wrasse, nor any kind of spiny fish, nor sea-crawfish, nor the spotted nor the spiny dog-fish; and, again, from this lagoon, all the fishes, save only a little gudgeon, migrated seaward to breed. And though with no special application to the island, but only to the Asiatic coast in general, I may add that the chameleon, which is the subject of one of Aristotle's most perfect and minute investigations, is here comparatively common, but is not known to occur. in Greece at all.

I take it then as probable, or even proven, that an important part of Aristotle's work in natural history was done upon the Asiatic coast, and in and near to Mitylene. ${ }^{1}$ He will be a lucky naturalist who shall go some day and spend a quiet summer by that calm lagoon,

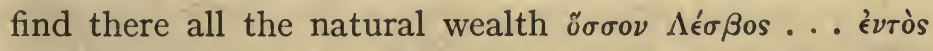

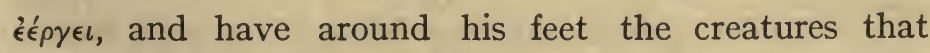
Aristotle loved and knew. Moreover, it follows for certain, if all this be true, that Aristotle's biological studies preceded his more strictly philosophical work; and it is of no small importance that we should be (as far as

1 Perhaps it was here also that Aristotle found his 'Lesbian rule'. 
possible) assured of this, when we speculate upon the influence of his biology on his philosophy. ${ }^{1}$

Aristotle is no tyro in biology. When he writes upon Mechanics or on Physics we read him with difficulty: his ways are not our ways; his explanations seem laboured; his science has an archaic look, as it were coming from another world to ours, a world before Galileo. Speaking with all diffidence, I have my doubts as to his mathematics. In spite of a certain formidable passage in the Ethics, where we have a sort of ethica more geometrico demonstrata, in spite of his favourite use of the. equality of the angles of a triangle to two right angles as an example of proof indisputable, in spite even of his treatise De Lineis Insecabilibus, I am tempted to suspect that he sometimes passed shyly beneath the superscription over Plato's door.

But he was, and is, a very great naturalist. When he treats of Natural History, his language is our language, and his methods and his problems are wellnigh identical with our own. He had familiar knowledge of a thousand varied forms of life, of bird and beast, and plant and creeping thing. He was careful to note their least details of outward structure, and curious to probe by dissection into their parts within. He studied the metamorphoses of gnat and butterfly, and opened the bird's egg to find the mystery of incipient life in the embryo chick. He

${ }^{1}$ Pursuing my geographical inquiries a very little further, I have discovered that of the very large number of place-names mentioned in the Problems, by far the greater number are situated in Southern Italy, that is to say in Magna Graecia, or in Sicily; and I live in hopes of seeing this work, or a very large portion of it, expunged, for this and other weightier reasons, from the canonical writings of Aristotle. In the treatise De Plantis, which is already acknowledged to be spurious, only three or four geographical names, I think, occur ; but they likewise are every one of them situated within the bounds of Magna Graecia. 
recognized great problems of biology that are still ours to-day, problems of heredity, of sex, of nutrition and growth, of adaptation, of the struggle for existence, of the orderly sequence of Nature's plan. Above all he was a student of Life itself. If he was a learned anatomist, a great student of the dead, still more was he a lover of the living. Evermore his world is in movement. The seed is growing, the heart beating, the frame breathing. The ways and habits of living things must be known: how they work and play, love and hate, feed and procreate, rear and tend their young; whether they dwell solitary, or in more and more organized companies and societies. All such things appeal to his imagination and his diligence. Even his anatomy becomes at once an anatomia animata, as Haller, poet and physiologist, described the science to which he gave the name of physiology. This attitude towards life, and the knowledge got thereby, afterwards helped to shape and mould Aristotle's philosophy.

I have no reason to suppose that the study of biology 'maketh a man wise', but I am sure it helped to lead Aristotle on the road to wisdom. Nevertheless he takes occasion to explain, or to excuse, his devotion to this study, alien, seemingly, to the pursuit of philosophy. 'Doubtless,' he says, 1 'the glory of the heavenly bodies fills us with more delight than we get from the contemplation of these lowly things; for the sun and stars are born not, neither do they decay, but are eternal and divine. But the heavens are high and afar off, and of celestial things the knowledge that our senses give us is scanty and dim. On the other hand, the living creatures are nigh at hand, and of each and all of them we may gain ample and certain knowledge if we so desire.

1 De Part. Anim. i. 5. 
If a statue please us, shall not the living fill us with delight; all the more if in the spirit of philosophy we search for causes and recognize the evidences of design. Then will Nature's purpose and her deep-seated laws be everywhere revealed, all tending in her multitudinous work to one form or another of the Beautiful.' In somewhat similar words does Bacon ${ }^{1}$ retranslate a familiar saying: 'He hath made all things beautiful according to their seasons; also he hath submitted the world to man's inquiry.' On the other hand, a most distinguished philosopher of to-day is struck, and apparently perplexed, by 'the awkward and grotesque, even the ludicrous and hideous forms of some plants and animals '.2 I commend him, with all respect, to Aristotle-or to that Aristotelian verity given us in a nutshell by Rodin, 'Il n'y a pas de laideur!'

To be sure, Aristotle's notion of beauty was not Rodin's. He had a philosopher's comprehension of the Beautiful, as he had a great critic's knowledge and understanding of Poetry; but wise and learned as he was, he was neither artist nor poet. His style seldom rises, and only in a few such passages as that which I have quoted, above its level didactic plane. Plato saw philosophy, astronomy, even mathematics, as in a vision; but Aristotle does not know this consummation of a dream. The bees have a king, with Aristotle. Had Plato told us of the kingdom of the bees, I think we should have had Shakespearian imagery. The king would have had his 'officers of sorts', his magistrates, and soldiers, his 'singing masons building roofs of gold'. Even Pliny, arid encyclopaedist as he is, can now and then throb and thrill us as Aristotle cannot do-for example, when

1 De Sapientia Veterum (Eccles. iii. II).

2 Ward, op. cit., p. 85. 
he throws no little poetry and still more of music into his description of the nightingale's song. ${ }^{1}$

But let us now come, at last, to exemplify, by a few brief citations, the nature and extent of Aristotle's zoological knowledge. And here, brevity bids me choose between two ways: either to deal with Aristotle's theories or his facts, his insight or his erudition. The former are of the highest possible interest to us, and their treatment partly includes the latter. But it would take more than all the time I have, to deal with any one of Aristotle's theories-of generation, for instance, or of respiration and vital heat, or those still weightier themes of variation and heredity, the central problems of biology, or again the teleological questions of adaptation and design.

Let me therefore confine myself, almost wholly, to a few fragments out of his storehouse of zoological and embryological facts.

Among the bloodless animals, as Aristotle called what we call the Invertebrates, he distinguishes four great genera, and of these the Molluscs are one. These are the cuttle-fish, which have now surrendered their Aristotelian name of 'molluscs' to that greater group, which is seen to include them with the shell-fish, or 'ostracoderma' of Aristotle. These cuttle-fishes are creatures that we seldom see, but in the Mediterranean they are an article of food, and many kinds are known to the fishermen. All, or wellnigh all, of these common kinds were known to Aristotle, and his account of them has come down to us with singular completeness. He describes their form and their anatomy, their habits, their development, all with such faithful accuracy that what we can add to-day seems of secondary importance. He begins with

${ }^{1}$ H. N. x. 43 (29). 
a methodical description of the general form, tells us of the body and fins, of the eight arms with their rows of suckers, of the abnormal position of the head. He points out the two long arms of Sepia and of the Calamaries, and their absence in the octopus; and he tells us, what was only confirmed of late, that with these two long arms the creature clings to the rock and sways about like a ship at anchor. He describes the great eyes, the two big teeth forming the beak; and he dissects the whole structure of the gut, with its long gullet, its round crop, its stomach and the little coiled caecal diverticulum; dissecting not only one but several species, and noting differences that were not observed again till Cuvier re-dissected them. He describes the funnel and its relation to the mantle-sac, and the ink-bag, which he shows to be largest in Sepia of all others. And here, by the way, he seems to make one of those apparent errors that, as it happens, turn out to be justified : for he tells us that in Octopus the funnel is on the upper side; the fact being that when the creature lies prone upon the ground, with all its arms spread and flattened out, the funnel-tube (instead of being flattened out beneath the creature's prostrate body) is long enough to protrude upwards between arms and head, and to appear on one side or other thereof, in a position apparently the reverse of its natural one. $\mathrm{He}$ describes the character of the cuttle-bone in Sepia, and of the horny pen which takes its place in the various Calamaries, and notes the lack of any similar structure in Octopus. He dissects in both sexes the reproductive organs, noting without exception all their essential and complicated parts; and he had figured these in his lost volume of anatomical diagrams. He describes the various kinds of eggs, and, with still more surprising knowledge, shows us the little embryo cuttle-fish, with its great 
yolk-sac, attached (in apparent contrast to the chick's) to the little creature's developing head.

But there is one other remarkable structure that he knew, centuries before it was rediscovered almost in our own time. In certain male cuttle-fishes, in the breeding season, one of the arms develops in a curious fashion into a long coiled whip-lash, and in the act of breeding may then be transferred to the mantle-cavity of the female. Cuvier himself knew nothing of the nature or the function of this separated arm, and indeed, if I am not mistaken, it was he who mistook it for a parasitic worm. But Aristotle tells us of its use and its temporary development, and of its structure in detail, and his description tallies closely with the accounts of the most recent writers.

Among the rarer species of the group he knew well the little Argonaut, with its beautiful cockle-shell, and tells how it puts up its two broad arms to sail with, a story that has been rejected by many, but that after all may perhaps be true.

Now in all this there is far more than a mass of fragmentary information gleaned from the fishermen. It is a plain orderly treatise, on the ways and habits, the varieties, and the anatomical structure of an entire group. Till Cuvier wrote there was none so good, and Cuvier lacked knowledge that Aristotle possessed.

Not less exact and scarcely less copious is the chapter in which Aristotle deals with the crab and lobster, and all such crustacean shell-fish, nor that in which he treats of insects, after their kind. Most wonderful of all, perhaps, are those portions of his books in which he speaks of fishes, their diversities, their structure, their wanderings, and their food. Here we may read of fishes that have only recently been rediscovered, ${ }^{1}$ of structures,

${ }^{1}$ e.g. Parasilurus Aristotelis, a siluroid fish of the Achelous. 
only lately reinvestigated, of habits only of late made known. ${ }^{1}$ And many such anticipations of our knowledge, and many allusions to things of which we are perhaps still ignorant, may yet be brought to light; for we are still far from having interpreted and elucidated the whole mass of Aristotle's recorded erudition: which whole recorded mass is only, after all, tanquam tabula naufragii.

There is perhaps no chapter in the Historia Animalium more attractive to the anatomist than one which deals with the anatomy and mode of reproduction of the cartilaginous fishes, the sharks and rays, a chapter which moved to admiration that prince of anatomists Johannes Müller. ${ }^{2}$ The latter wrote a volume on the text of a page of Aristotle, a page packed full of a multitude of facts, in ¿ no one of which did Johannes Müller discover a flaw. The subject is technical, but the gist of the matter is this : that among these Selachians (as, after Aristotle, we still sometimes call them) there are many diversities in the structure of the parts in question, and several distinct modes in which the young are brought forth or matured. For in many kinds an egg is laid, which eggs, by the way, Aristotle describes with great minuteness. Other kinds do not lay eggs, but bring forth their young alive, and these include the Torpedo and numerous sharks or dogfish. The eggshell is in these cases very thin, and breaks before the birth of the young. But among them there are a couple of sharks, of which one species was within

1 e.g. the reproduction of the pipe-fishes (Syngnathi), the hermaphrodite nature of the Serrani, the nest-building of the Wrasses, \&c., \&c.

2 Cf. Cavolini, in his classical Mem. sulla Generazione dei Pesci, Naples, I787: 'E quando io ... scorro la Storia degli Animali di Aristotile, non posso non essere da stupore preso, in esse leggendo veduti quei fatti, che a noi non si son potuti che a stento manifestare: e rilevati poi con tutta la nettezza, e posti in parallelo coi fatti già riconosciuti nel feto del gallo; ' \&c. 
Aristotle's reach, where a very curious thing happens. Through the delicate membrane, which is all that is left of the eggshell, the great yolk-sac of the embryo becomes connected with the parental tissues, which infold and interweave with it ; and by means of this temporary union the blood of the parent becomes the medium of nourishment for the young. And the whole arrangement is physiologically identical with what obtains in the higher animals, the mammals, or warm-blooded vivipara. It is true that the yolk-sac is not identical with that other embryonic membrane which comes in the mammals to discharge the function of which I speak ; but Aristotle was aware of the difference, and distinguishes the two membranes with truth and accuracy.

It happens that of the particular genus of sharks to which this one belongs, there are two species differing by almost imperceptible characters ; but it is in one only of

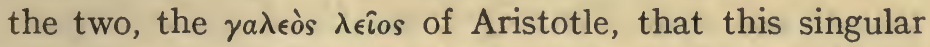
phenomenon of the placenta vitellina is found. It is found in the great blue shark of the Atlantic and the Mediterranean; but this creature grows to a very large size before it breeds, and such great specimens are not likely to have come under Aristotle's hands. Cuvier detected the phenomenon in the blue shark, but paid little attention to it, and, for all his knowledge of Aristotle, did not perceive that he was dealing with an important fact which the Philosopher had studied and explained. In the seventeenth century, the anatomist Steno actually

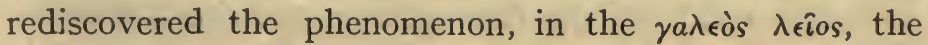
Mustelus laevis itself, but he was unacquainted with Aristotle. And the very fact was again forgotten until Johannes Müller brought it to light, and showed not only how complete was Aristotle's account, but how wide must have been his survey of this class of fishes to enable 
him to record this peculiarity in its relation to their many differences of structure and reproductive habit. I used to think of this phenomenon as one that Aristotle might have learned from the fishermen, but, after a more careful study of Johannes Müller's book, I am convinced that this is not the case. It was a discovery that could only have been made by a skilled and learned anatomist.

In a lengthy and beautiful account Aristotle describes the development of the chick. It is on the third day that the embryo becomes sufficiently formed for the modern student to begin its study, and it was after just three days (a little earlier, as Aristotle notes, in little birds, a little later in larger ones) that Aristotle saw the first clear indication of the embryo. Like a speck of blood, he saw the heart beating, and its two umbilical blood-vessels breaking out over the yolk. A little later he saw the whole form of the body, noting the disproportionate size of head and eyes, and found the two sets of blood-vessels leading, the one to the yolk-sac, the other to the new-formed allantois. In the tiny chick of the tenth day, he saw the stomach and other viscera; he noted the altered position of the heart and great blood-vessels; he traced clearly and fully the surrounding membranes; he opened the little eye to seek, but failed to find, the lens. And at length he describes in detail the appearance and attitude of the little chick, the absorption of the yolk, the shrivelling of the membranes, just at the time when the little bird begins to chip the shell, and before it steps out into the world. While this epitome contains but a part $r$ of what Aristotle saw (and without a lens it would be hard to see more than he), it includes the notable fact of the early appearance of the heart, the punctum saliens of later writers, whose precedence of all other organs was a chief reason for Aristotle's attributing to it a common, 
central, or primary sense, and so locating in it the central seat of the soul. And so it was held to be till Harvey's time, who, noting the contemporaneous appearance of heart and blood, held that the contained was nobler than that which contained it, and that it was the blood that was ' the fountain of life, the first to live, the last to die, the primary seat of the soul, the element in which, as in a fountain-head, the heat first and most abounds and flourishes'; so harking back to a physiology more ancient than Aristotle's - ' for the blood is the life thereof.' All students of the Timaeus know that here Aristotle parted company with Plato, who, following Hippocrates, and Democritus, and others, placed the seat of sensation, the sovereign part of the soul, in the brain. Right or wrong, it was on observation, and on his rarer use of experiment, ${ }^{1}$ that Aristotle relied. The wasp or the centipede still lives when either head or tail is amputated, the tortoise's heart beats when removed from the body, and the heart is the centre from which the blood-vessels spring. To these arguments Aristotle added the more idealistic belief that the seat of the soul, the ruling force of the body, must appropriately lie in the centre : and he found further confirmation of this view from a study of the embryo plant, where in the centre, between the seedleaves, is the point from which stem and root grow. And Ogle reminds us how, until a hundred years ago, botanists still retained an affectionate and superstitious regard for that portion of the plant, calling it now cor, now cerebrum, the plant's heart or brain.

And now is it possible to trace directly the influence of Aristotle's scientific training and biological learning upon

'Aristotle's experiments were akin to Voltaire's, who employed himself in his garden at Ferney in cutting off the horns and heads of snails, to see whether, or how far, they grew again. 
his sociolggy, his psychology, or in general on his philosophy? That such an influence must have been at work is, prima facie, obvious. The physician who becomes a philosopher will remain a physician to the end; the engineer will remain an engineer; and the ideas of pure mathematics, Roger Bacon's 'alphabet of philosophy', will find issue and expression in the philosophy of such mathematicians as Plato, Leibnitz, Spinoza, or Descartes. Moreover, it is not only the special training or prior avocation of the philosopher that so affects his mind. In divers historical periods the rapid progress or the diffused study of a particular science has moulded the philosophy of the time. So on a great scale in the present day does biology; so did an earlier phase of evolutionary biology affect Hegel ; and in like manner, in the great days after Lavoisier, the days of Dalton, Davy and Berzelius, did chemistry help, according to John Stuart Mill, to suggest a ' chemistry of the mind ' to the 'association ' psychologists. A certain philosopher, ${ }^{1}$ in dealing with this theme, begins by telling us that 'Mathematics was the only science that had outgrown its merest infancy among the Greeks'. Now it is my particular purpose to-day to show, from Aristotle, that this is not the case. Whether Aristotle's biological forerunners were many or few, whether or not the Hippocratics (for instance) had failed to raise physiology and anatomy to the dignity of a science, or having done so, had only reserved them, as a secret cult, to their own guild; in short, whether Aristotle's knowledge is in the main the outcome of his solitary labours, or whether, as Leibnitz said of Descartes, praeclare in rem suam vertit aliorum cogitata, it is at least certain that biology was in his hands a true and comprehensive science, only second to the mathematics of his age.

${ }^{2}$ Ritchie, Darwin and Hegel, p. 39. 
The influence, then, of scientific study, and in particular of Biology, is not far to seek in Aristotle's case / It has ever since been a commonplace to compare the state, the body politic, with an organism, but it was Aristotle who first employed the metaphor. Again, in his exhaustive accumulation and treatment of political facts, his method is that of the observer, of the scientific student, and is in the main inductive. Just as, in order to understand fishes, he gathered all kinds together, recording their forms, their structure, and their habits, so he did with the Constitutions of cities and of states. Those two hundred and more $\pi$ лолтєia which Aristotle laboriously compiled, after a method of which Plato would never have dreamed, were to form a Natural History of Constitutions and Governments. And if we see in his concrete, objective treatment of the theme a kinship with Spencer's Descriptive Sociology, again, I think, a difference is soon apparent, between Spencer's colder catalogue of facts and Aristotle's more loving insight into the doings and into the hearts, into the motives and the ambitions, of men.

But whatever else Aristotle is, he is the great Vitalist, the student of the Body with the Life thereof, the historian of the Soul,

Now we have already seen how and where Aristotle fixed the soul's seat and local habitation. But the soul has furthermore to be studied according to its attributes, or analysed into its 'parts'. Its attributes can be variously analysed, as in his Ethics Aristotle shows. But it is in the light of Biology alone that what amounts to a scientific analysis, such as is developed in the $D e$ Anima, becomes possible ; and in that treatise it is only after a long preliminary physiological discussion that Aristotle at length formulates his distinctive psychology. There is a principle of continuity, a $\sigma v \varepsilon^{\prime} \chi \epsilon \iota a$, that runs 
through the scale of structure in living things, and so, little by little, by imperceptible steps, does Nature make the passage from plant, through animal, to man. It is with all the knowledge, summarized in a great passage of the Natural History, and embodied in this broad generalization, that Aristotle afterwards proceeds to indicate the same gradation in psychology, and to draw from it a kindred classification of the Soul.

There is a soul which presides over the primary physiological requirement of nutrition, a soul already inherent in the plant and inseparable from life itself; it is $\dot{\eta} \pi \rho \omega \dot{\tau} \eta$ $\psi v x \eta$. Common likewise to all living things are the physiological functions of growth and reproduction, and the psychical agencies directing these are concomitant with, and in fact identical with, the nutrient soul. Sensation or sensibility, whereby the animal essentially differs from the plant, distinguishes the ai $\sigma \theta \eta$ rıкो $\psi v \times \eta^{\prime}$, the sentient soul; and the soul of movement, undisplayed in the very lowest of animals, presently accompanies the soul of sensibility. At length the reasoning soul, the

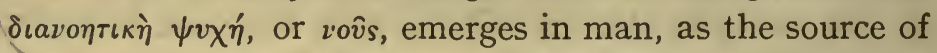
his knowledge and his wisdom. ${ }^{1}$ In a brief but very important passage, ${ }^{2}$ with a touch of that Platonic idealism never utterly forgotten by him (and so apt to bring Wordsworth to our own minds), Aristotle tells us

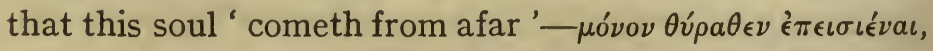

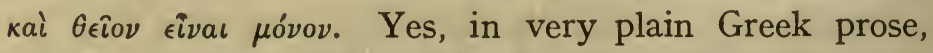
this is no less than to assert that 'trailing clouds of glory', 'it cometh from afar.'

But however glorified be the reasoning soul, yet these parts, these subdivisions of the soul, do not stand apart in

1 I have here borrowed some words from a former address, and from my notes on the Historia Animalium.

- De Gen. An. ii. 3, 736 b 27. Cf. Brentano, Aristoteles' Lehre vom Ursprung des menschlichen Geistes, I9I1, p. 18. 
mutual exclusiveness, but just as we may discern a triangle within a square, so is each lower grade of $\psi v \times \eta^{\prime}$ implicit in the higher. And as the higher organisms retain the main physiological faculties of the lower, so do they retain such psychological qualities as these possess: and gradually (more and more as we ascend the ladder) do we find adumbrations of the psychical qualities that will be perfected in the higher forms. Among the higher animals, at least, a comparative psychology may be developed ; for just as their bodily organs are akin to one another's and to man's, so also have we in animals an inchoate intelligence, wherein we may study, in one or another, the psychology of such things as fear, anger, courage, and at length of something which we may call sagacity, which stands not far from reason. And, last of all, we have a psychology of childhood, wherein we study in the child, at first little different from the animal, the growing seeds of the mind of man.

But observe before we leave this subject that, though Aristotle follows the comparative method, and ends by tracing in the lower forms the phenomena incipient in the higher, he does not adopt the method so familiar to us all, and on which Spencer insisted, of first dealing with the lowest, and of studying in successive chronological order the succession of higher forms. The historical method, the realistic method of the nineteenth century, the method to which we so insistently cling, is not the only one. Indeed, even in modern biology, if we compare (for instance) the embryology of to-day with that of thirty years ago, we shall see that the pure historical method is relaxing something of its fascination and its hold. Rather has Aristotle continually in mind the highest of organisms, in the light of whose integral and constituent phenomena must the less perfect be understood. So was 
it with one whom the Lord Chancellor of England has called 'the greatest master of abstract thought since Aristotle died '. For Hegel, ${ }^{1}$ as surely for Aristotle also, Entwicklung was not a 'time-process but a thought\{process'. To Hegel, an actual, realistic, outward, historical evolution seemed but a clumsy and materialistic philosophy of nature. In a sense, the 'time-difference has no interest for thought'. And if the lower animals help us to understand ourselves, it is in a light reflected from the study of Man.

So grows up, upon a broad basis of Natural History, the whole psychology of Aristotle, and in particular that great doctrine of the tripartite soul, according to which created things 'by gradual change sublimed, To vital spirits aspire, to animal, To intellectual!'

In this $\psi v \times \eta^{\prime}$ of Aristotle there was (in spite of the passage which I have quoted) a trace of the concrete and the all but material, which later Greek as well as Christian thought was not slow to discern and to modify. But, as a philosopher of our own day reminds us, it was in relation to a somewhat idealized Body that Aristotle described that somewhat unspiritual Soul. Such as it is, it has remained at the roots of our psychology, even to this day.

Bergson only partially gets rid of it when he recasts Aristotelian psychology on the lines of that branching tree which modern evolutionary biology subIstitutes for the scala Naturae of Aristotle; rand when he sees, for instance, in psychological evolution, not the successive grades of continuous development, through sensibility and instinct to intelligence, but rather the splitting up of an original activity, of which instinct

1 Ritchie, op. cit. Cf. Höffding, in Darwin and Modern Science. Cambridge, r 909 , p. 449. 
and intelligence are not successive, but separate and diyerging, outgrowths.

In our recent science the Aristotelian doctrine is not dead. For but little changed, though dressed in new garments, this Aristotelian entelechy, ${ }^{1}$ which so fascinated Leibnitz, ${ }^{2}$ enters into the Vitalism of Hans Driesch; and of those who believe with him, that far as physical laws may carry us, they do not take us to the end : that the limitations of induction forbid us to pass in thought and argument from chemistry to consciousness, or (as Spencer well knew) from Matter to Mind ; ${ }^{3}$ that Life is not merely ' an outstanding difficulty, but a veritable exception to the universal applicability of mechanical laws'; that not to be comprehended under the category of physical cause, but to be reckoned with apart, is the fundamental conception underlying Life and its Teleology. ${ }^{4}$

It is easy so to sketch in simple words the influence of Aristotle's biological studies upon his method of work, or to see in his Psychology and his Ethics the results of his biological analysis of the soul. But his natural science seems to send a still deeper influence running through the whole of his philosophy, for better or for worse, which

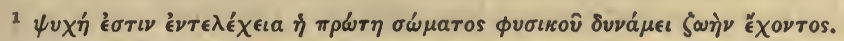

- Cf. Jacoby, De Leibnitii studiis A ristotelicis, Berlin, 1867.

'Cf. Spencer, Princ. of Psychology (para. 63): "Though of the two it seems easier to translate so-called Matter into so-called Spirit, than to translate so-called Spirit into so-called Matter (which latter is indeed wholly impossible); yet no translation can carry us beyond our $\{$ symbols. Such vague conceptions as loom before us are illusions con'jured up by the wrong connotations of our words.'

- Cf. Kant's views in the Kritik der Urteilskraft and elsewhere, on the teleological aspect of living organisms, with (for instance) Schleiden in the Preface to his Grundzüge der Botanik (1860): '... durch die Darwinsche Lehre die Teleologie aus der Naturwissenschaft vollständig heraus, und in die erbauliche oder poetische Rede, wo sie hingehört, verwiesen wurde!' Cf. also Professor Sidgwick's remarks on Spencer's 'avoidance of teleological explanation', in the Ethics of T. H. Green, \&c., p. I4I. 
influence I lack the needful learning to fathom and to i describe. I can only see dimly, and cannot venture to explain, how his lifelong study of living things led to his rejection of Plato's idealistic ontology, and affected his whole method of classification, his notion of essentials and accidents, his idea of 'Nature' that 'makes nothing in vain', his whole analysis of causation, his belief in, and his definition ${ }^{1}$ of, Necessity, his faith in design, his particular form of teleology, his conception and appreLhension of God.

And now, to close my story. It is in no derogation of Spencer's commemorative honour that I have spoken of him together with a greater Philosopher, and one of the greatest of men. So I have used my hour of Oxford to speak, and to salute, the name of Aristotle, here where his spirit has dwelt for six hundred years-I who have humbly loved him since my day began.

We know that the history of biology harks back to Aristotle by a road that is straight and clear, but that beyond him the road is broken and the lights are dim. And we have seen that biology was no mere by-play of Aristotle's learned leisure, but was a large intrinsic part of the vast equipment of his mind.

This our science is no petty handicraft, no narrow discipline. It was great, and big, in Aristotle's hands, and it is grown gigantic since his day.

It begins in admiration of Nature's handiwork, as she strews it by the way. It bids us seek through the land, and search the deep places of the sea. It toils for the health and wealth of men. It speaks of things humble; it whispers of things high. It tells (if I dare use the old theologian's word ${ }^{2}$ ) of Laws, 'whose Voice is the harmony of the World, and whose Seat is the bosom of God.' 


\section{ARISTOTLE AS A BIOLOGIST}

Sometimes, as to-day, it brings us by a by-way to the study of the history of human thought and knowledge, and introduces us to a company of great men, dwellers in the 'clear air' of Athens.

The little Greek I know, first learnt at my Father's knee, is but a child's plaything to that of many a scholar here. But I hear, now and then, a welcome given, in old Hellenic speech, to men who call at that Interpreter's House wherein Plato and Aristotle show us 'excellent things, such as will be a help to us in our journey'. 




\section{RETURN CIRCULATION DEPARTMENT}

IO $\longrightarrow 202$ Main Library

LOAN PERIOD $1 / 2$

RETURN TO the circulation desk of any

University of California Library

or to the

NORTHERN REGIONAL LIBRARY FACILITY

Bldg. 400, Richmond Field Station

University of California

Richmond, CA 94804-4698

ALL BOOKS MAY BE RECALLED AFTER 7 DAYS

2-month loans may be renewed by calling

(510) 642-6753

1-year loans may be recharged by bringing books to NRLF

Renewals and recharges may be made 4 days prior to due date

\section{DUE AS STAMPED BELOW}

\section{APR 121994}

FEB 212007

OCT.09 2007! 


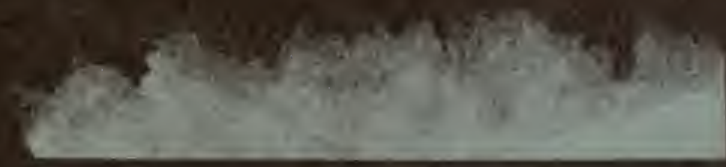

GENERAL LIBRARY - U.C. BERKELEY

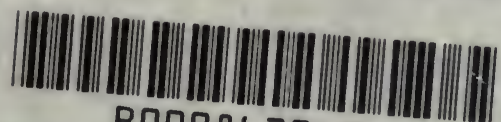
B000863943 
